\title{
Innovations and high-tech export as a basis of sustainable development
}

\author{
Oksana Falchenko ${ }^{1,}$, Irina Savelyeva ${ }^{1}$, Veronika Vyazovskaya ${ }^{1}$, and Luis Cesar Molina \\ Almanza $^{2}$ \\ ${ }^{1}$ Ural State University of Economics, World Economy and Foreign Economic Activity Department, \\ 620144 Yekaterinburg, Russia \\ ${ }^{2}$ Public Institute of Higher Technological Education "Simon Bolivar”, Bellavista 07011 Lima, Peru
}

\begin{abstract}
The article is devoted to the analysis and assessment of the relationship between innovative and sustainable development of economies in the context of Eurasian integration. Using a two-stage methodological approach, the authors assess the level of innovative development of the EAEU countries and investigate the hypothesis that there is a correlation between the innovative activities of enterprises and the growth of high-tech exports, which serves as the basis for achieving sustainable development of the integration association. Conclusions were obtained about the ambiguity and inconsistency of the calculation model results for individual members of the integration association, connected with different starting levels of innovative development of the EAEU countries, as well as a number of other factors.
\end{abstract}

\section{Introduction}

Integration associations, including the individual countries as their parts, set themselves the goal achievement of sustainable development, especially relevant in the face of modern global challenges. Integration processes are formed under the influence of economic interests combination, cultural constituent, political will, and other potentially significant factors that modify the socio-economic space of the merging territories. The long-term result of integration is revealed through the achievement of sustainable development of individual economies as part of a regional association. A debatable issue focused on the search for such factors that determine the basis for sustainable development of integrating states. Today, most researchers are inclined to conclude that a sustainable development is impossible without an innovative renewal of the economy.

The global transition to a new technological order determines the relationship between the sustainable development of national economies and an increase in the innovative activity of enterprises, an increase in production and export of high-tech products. In modern studies, there is a close relationship between innovation and international trade [1].

In recent decades, there has been a systematic increase in the share of developing countries in the world exports. Relying on innovation as one of the key export factors,

\footnotetext{
*Corresponding author: falchenko@usue.ru
} 
developing countries have increased their positions in the global innovation index (Global Innovation Index, GII) [2].

The purpose of the article is to assess the level of innovative activity and develop recommendations for the formation of the basis for sustainable development of the economy on the platform of high-tech exports. The object of the study is the countries that are viewed as part of the Eurasian Economic Union (hereinafter - the EAEU) - Russia, Belarus, Kazakhstan, Armenia, Kyrgyzstan.

\section{Theoretical Framework}

The sustainable development concept of the United Nations (sustainable development) [3] forms a new field of economic research in the innovation sphere. Economic integration within the EAEU is aimed at becoming an additional factor contributing to the goal achievement of sustainable development by the member countries of the Union: for example, the implementation of the 9th goal - "Industrialization, innovation and infrastructure" - involves the creation of "resilient infrastructure, promoting inclusive and sustainable industrialization and innovation", which is impossible without stimulating innovation [4].

Most researchers agree that innovations are a driver of socio-economic development and a technological basis for economic growth for the transition of socio-economic systems to a new qualitative level. The theoretical basis for research on the mutual influence of innovation and sustainable development was introduced in the papers of Andrew Reamer (2014) [5]; Daron Acemoglu and James A. Robinson (2012) [6]; James Broughel and Adam Thierer (2019) [7]. Maradana, R.P., Pradhan, R.P., Dash, S. et al. (2017) investigate the long-term relationship between innovation and per capita growth in 19 European countries during the period from 1989 to 2014. [8].

Russian studies on the mutual influence of innovation and sustainable development were carried out by Mityakov, E. S .; Shiryaev, M. V .; Mityakov, S. N .; Mityakova, O. I .; Yakovleva, N. N. (2017) [9], R.O. Isaev (2019) [10]; E.V. Shilova (2015) [11] and others.

The study of the relationship between innovation and high-tech exports is analyzed in the works of Sandu, Steliana \& Ciocanel, Bogdan (2014) [12]; Muhammad Usman (2019) [13] and others. Analysis of the mutual influence of innovation and export was undertaken by Russian researchers S. M. Asanseitova, V. G. Svinukhov, E. V. Kovaleva (2018) [14]; S.I. Fayazova (2020) [2]; N.V. Linder (2020) [15]. The trade effects of integration associations are analyzed in the work of V.E. Kovalev et al. (2017) [16].

\section{Methods}

Based on the methodological approaches used in the scientific literature to assess the level of innovative development of countries and integration associations, we propose the following scheme for analyzing the level of innovative development of the EAEU.

The first stage of the study is to assess the level of innovative development of the EAEU countries and its relationship with high-tech exports. To do this, we have analyzed the positions of the EAEU countries in the Global Innovation Index, presented a graphical interpretation of the dynamics of high-tech exports to third countries, domestic investment in $R \& D$, and personnel engagement in $R \& D$.

The second stage of the study was to test the hypothesis about the influence of innovation activity indicators on high-tech exports of the EAEU countries. This hypothesis is proposed to be tested by using the regression analysis tools. 
The study implements a model that links the volume of high-tech exports HTEt in period t to the number of people employed in research and development (RDEMPt) and the volume of internal expenditure on research and development (RDEXPt).

This dependence can be expressed by the following formula:

$$
H T E_{t}=f\left(R D E M P_{t} ; R D E X P_{t}\right),
$$

where:

$H T E_{t}$-a high-tech export volume, USD, USA ;

$R D E M P_{t}$ - number of personnel engaged in research and development by category, people;

$R D E X P_{t}$ - internal expenditures on research and development, USD, USA.

By representing this function in logarithmic form, the following equation can be drawn up:

$$
\ln H T E_{t}=\alpha+\beta_{1} \times \ln R D E M P_{t}+\beta_{2} \times \ln R D E X P_{t}+\varepsilon
$$

where:

$\ln H T E_{t}$-natural logarithm of high-tech exports;

$\ln R D E M P_{t}$ - natural logarithm of R\&D personnel by category;

$\ln R D E X P_{t}$ - natural logarithm of internal $\mathrm{R} \& \mathrm{D}$ expenditures

$\alpha$-constant;

$\beta_{1,2}$-regression coefficients;

$\varepsilon$-leftovers;

$t$-analyzed period.

The information base of the study was drawn up by regulatory legal acts, data from analytical studies and reports on the EAEU countries development, statistical materials of international economic organizations and rating agencies. The empirical base of the study includes data from the official statistics of the EAEU and international economic organizations (the World Bank, etc.).

\section{Results and conclusions}

The $1^{\text {st }}$ research stage. Evaluating the positions of the EAEU countries in the Global Innovation Index, we come to the conclusion that the position of the EAEU countries is below the average. The dynamics of this indicator within the EAEU countries is presented in Table 1.

Table 1. Dynamics of the global innovation index by EAEU countries for 2012-2020.

\begin{tabular}{|l|l|l|l|l|l|l|l|l|l|}
\hline Year & $\mathbf{2 0 1 2}$ & $\mathbf{2 0 1 3}$ & $\mathbf{2 0 1 4}$ & $\mathbf{2 0 1 5}$ & $\mathbf{2 0 1 6}$ & $\mathbf{2 0 1 7}$ & $\mathbf{2 0 1 8}$ & $\mathbf{2 0 1 9}$ & $\mathbf{2 0 2 0}$ \\
\hline Number of countries & 141 & 142 & 143 & 141 & 128 & 127 & 126 & 129 & 131 \\
\hline Armenia & 69 & 59 & 65 & 61 & 60 & 59 & 68 & 64 & 61 \\
\hline Belarus & 78 & 77 & 58 & 53 & 79 & 88 & 86 & 72 & 64 \\
\hline Kazakhstan & 83 & 84 & 79 & 82 & 75 & 78 & 74 & 79 & 77 \\
\hline Kyrgyzstan & 109 & 117 & 112 & 109 & 103 & 95 & 94 & 90 & 94 \\
\hline Russia & 51 & 62 & 49 & 48 & 43 & 45 & 46 & 46 & 47 \\
\hline $\begin{array}{l}\text { EAEU (weighted } \\
\text { average) }\end{array}$ & 55 & 65 & 52 & 52 & 47 & 50 & 50 & 50 & 51 \\
\hline
\end{tabular}

Source: Compiled and updated by the authors based on the Global Innovation Index https://www.globalinnovationindex.org/about-gii\#reports

The indicator dynamics of the innovation activity of the EAEU countries is shown in Figure 1. During the period under review, there is no complete correlation of the parameters 
under consideration (the cost of high-tech exports, the volume of internal R\&D expenditures, the number of personnel engaged in R\&D). The volume of domestic investment in R\&D lags far behind the volume of high-tech exports within all EAEU countries.
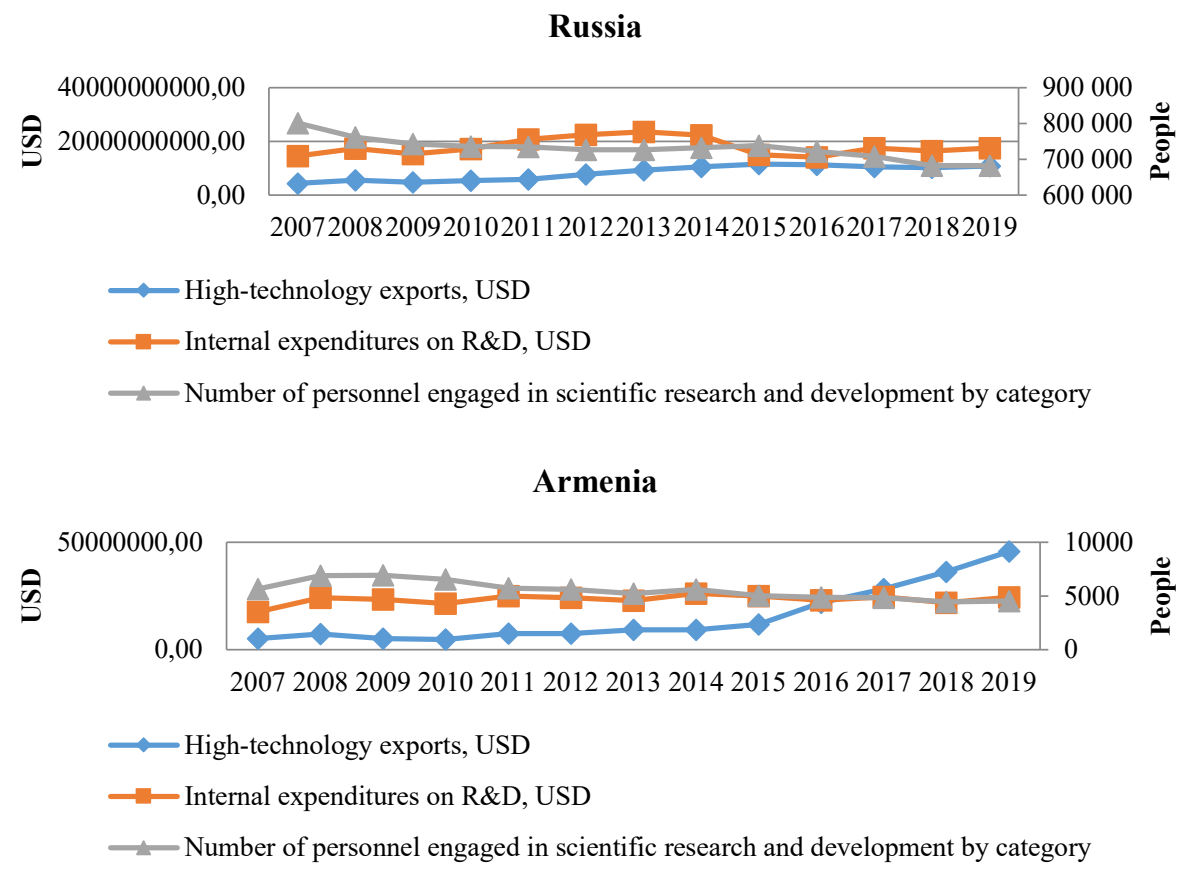

\section{Belarus}

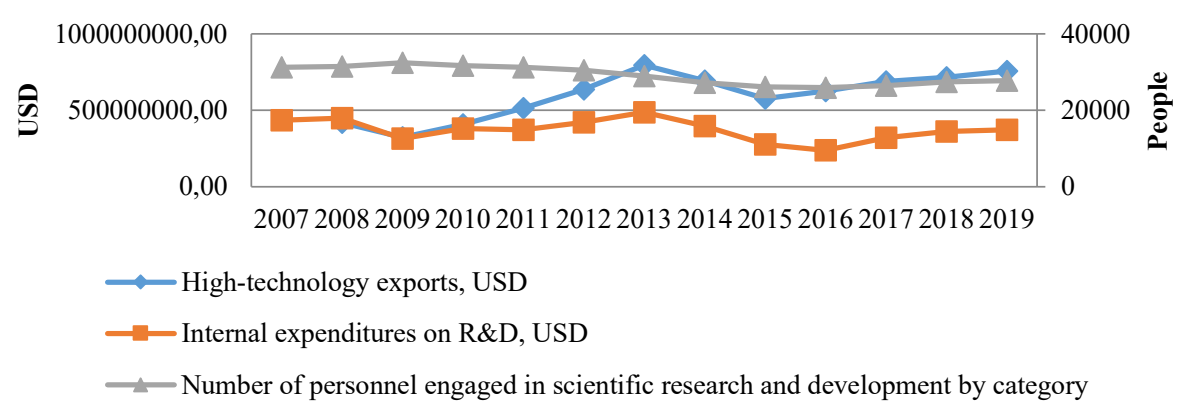

\section{Kazakhstan}

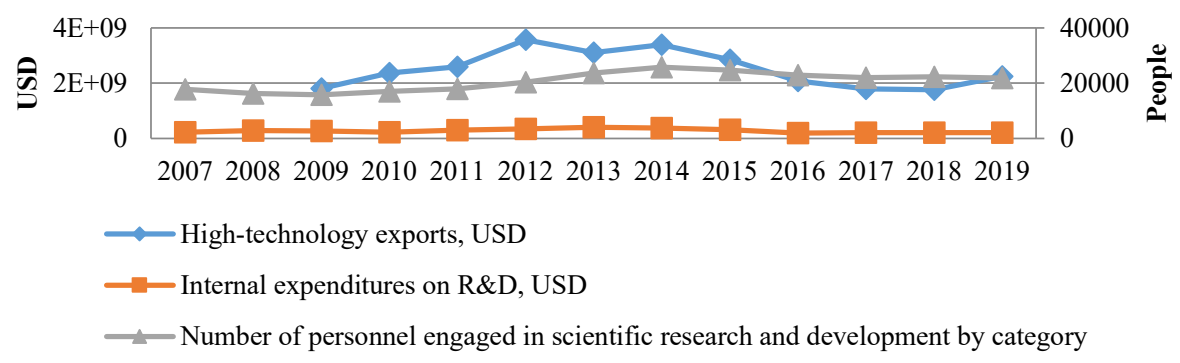




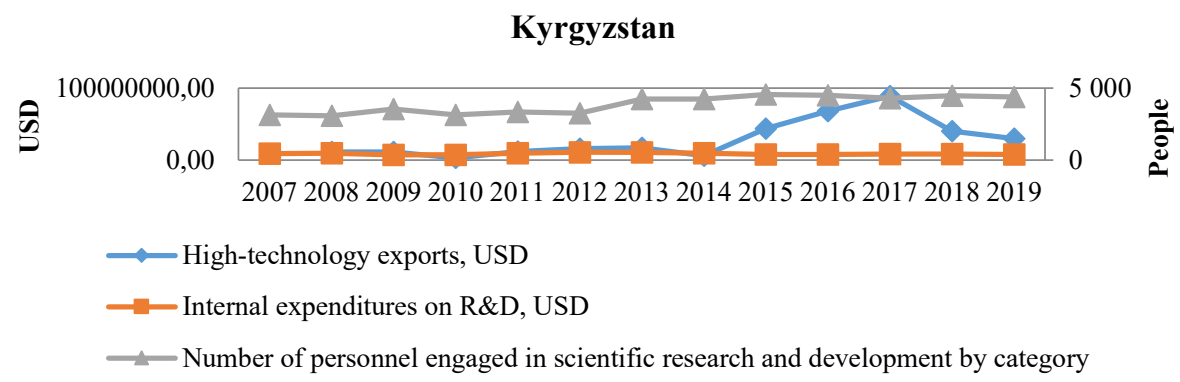

Fig. 1. Dynamics of high-tech exports, the volume of domestic R\&D expenditure and the number of personnel engaged in R\&D within the EAEU countries in 2007-2019 [Source: compiled and supplemented by the authors based on data from the World Bank and the Eurasian Economic Commission]

The $2^{\text {nd }}$ research stage. The data sources were time - series indicators from the databases of the World Bank and the Eurasian Economic Commission of the EAEU for the period 2007-2019. In the research, we used the least - squares method, in which several statistical tests were carried out by using the MS Excel program. To obtain the results, calculations were performed by implementing the regression equation. The main results of statistical tests are shown in Table 2.

Table 2. Regression coefficients (dependent variable - lnHTEt - high-tech export) and summary statistics.

\begin{tabular}{|c|c|c|}
\hline Country & Calculation results & Interpretation \\
\hline Russia & $\begin{array}{c}\ln \mathrm{HTEt}=105,9819-6,16782 \\
\operatorname{lnRDEMPt}+0,00292 \ln \\
\text { RDEXPt }_{\mathrm{t}}\end{array}$ & $\begin{array}{l}\text { A significant parameter of the model is } \\
\text { lnRDEMPt ( } \mathrm{t} \text {-statistic }=3.13583>2 ; \mathrm{P} \text {-value }= \\
1 \%<5 \% \text {; coefficient of determination }=0.504> \\
0.5)\end{array}$ \\
\hline Armenia & $\begin{array}{c}\operatorname{lnHTEt}=29,94965- \\
4,49491 \ln R \mathrm{REMPt}^{+1,4736181} \\
\mathrm{n} \mathrm{RDEXP}\end{array}$ & $\begin{array}{l}\text { A significant parameter of the model is } \\
\text { lnRDEMPt }(\mathrm{t} \text {-statistic }=6,01868>2 ; \mathrm{P}-\mathrm{value}=0 \% \\
<5 \% \text {; coefficient of determination }=0,797>0,5)\end{array}$ \\
\hline Belarus & $\begin{array}{c}\operatorname{lnHTEt}=41,79246-- \\
3,74984 \ln R D E M P t+0,8565681 \\
\text { n RDEXPt }\end{array}$ & 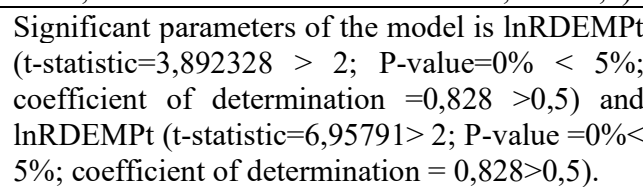 \\
\hline Kazakhstan & $\begin{array}{c}\operatorname{lnHTEt}=- \\
6,79322+1,101314 \ln R D E M P t \\
+0,893344 \ln \text { RDEXP }_{t}\end{array}$ & $\begin{array}{l}\text { A significant parameter of the model is } \\
\text { lnRDEXPt ( } \mathrm{t} \text {-statistic }=2.152591>2 ; \mathrm{P} \text {-value }= \\
5 \% \text {; coefficient of determination is greater than } \\
0.501) \text {. }\end{array}$ \\
\hline Kyrgyzstan & $\begin{array}{c}\operatorname{lnHTEt}=- \\
17,1661+4,157938 \ln R D E M P t- \\
0,02463 \ln \text { RDEXP }_{\mathrm{t}}\end{array}$ & $\begin{array}{l}\text { A significant parameter of the model is } \\
\text { lnRDEMPt }(\mathrm{t} \text {-statistic }=2.952027>2 ; \mathrm{P} \text {-value }= \\
1 \%<5 \% \text {; the coefficient of determination is close } \\
\text { to } 0.5) \text {. }\end{array}$ \\
\hline
\end{tabular}

Source: the authors' own calculations based on the statistics of the World Bank and the EEC, carried out by using the MS Excel data analysis package.

Therefore:

- The obtained results are not unambiguous for all EAEU countries. This model is a two-factor one, not taking into account any changes in other important indicators that directly affect the size of high-tech exports. This model is intended only to assess the impact of innovative indicators on the volume of high-tech exports. 
- Not all coefficients of the model turned out to be significant: for Russia, Armenia and Kyrgyzstan, the dependence of high-tech exports on the number of personnel engaged in research and development seemed to be a significant factor; for Belarus, the dependence of high-tech exports on the number of personnel engaged in research and development and internal expenditures were considered as significant factors for research and development; for Kazakhstan, a significant factor turned out to be the dependence of high-tech exports on domestic spending in research and development. This contradiction is determined by the following factors: 1) an insignificant share of high-tech exports of the EAEU countries, which is explained by the raw-material orientation of trade with third countries; 2) it can be assumed that the inverse relationship between the volume of high-tech exports and the number of personnel engaged in $R \& D$ is determined by the low labor intensity, the low competitiveness and the production orientation of innovative products to the domestic market; 3 ) inconsistency in a number of statistical data to the international standards.

- The obtained results ambiguity indicates the need for further scientific research for effective models. The sustainable development goals require model revision and statistics data extension for relevant assessment and hypothesis testing.

\section{References}

1. R.R. Mustafayeva, N.A. Narimanov, Russian Journal of Innovation Economics, 10, 1 (2020)

2. S.I. Faiazova, Strategic decisions and risk management, 11, 1 (2020)

3. Mainstreaming the 2030 Agenda for Sustainable Development (2017)

4. Indicators of achieving sustainable development goals in the region of the Eurasian Economic Union. Report of the Eurasian Economic Commission (2017)

5. A.Reamer, The Impacts of Technological Invention on Economic Growth. A Review of the Literature (2014)

6. D. Acemoglu, J.A. Robinson, Why Nations Fail: The Origins of Power, Prosperity, and Poverty (New York: Crown Business, 2012)

7. J. Broughel, A. Thierer, Technological Innovation and Economic Growth: A Brief Report on the Evidence (Mercatus Research, Mercatus Center at George Mason University, Arlington, VA, 2019)

8. R.P. Maradana, R.P. Pradhan, S. Dash, et al, J Innov Entrep 6, 1 (2017)

9. E.S. Mityakov, M.V. Shiryaev, S.N. Mityakov, O.I. Mityakova, N.N. Yakovleva, 4th International Multidisciplinary Scientific Conference on Social Sciences and Arts SGEM 2017, 4 (2017)

10. R.O. Isaev, Creative Economy, 13, 11 (2019)

11. E.V. Shilova, Vestnik Permskogo universiteta. Seria Ekonomika, Perm University Herald. Economy, 2, 25 (2015)

12. S. Sandu, B. Ciocanel, Procedia Economics and Finance, 15 (2014)

13. U. Muhammad, Journal on Innovation and Sustainability, 10, 1 (2019)

14. S.M. Assanseitova, V.G. Svinukhov, E.V. Kovaleva, International Trade and Trade Policy, 1 (2018)

15. N.V. Linder, Innovative Development of the Economy, 3 (2020) 
16. V. Kovalev, O. Falchenko, V. Vyazovskaya, V. Maydanik, Global and National Business Theories and Practice: Bridging the Past with the Future: 10th Annual Conference of the EuroMed Academy of Business (EuroMed Press, 2017) 